\title{
Adjustment of In-Depth Interview and Focus Group Discussion Guidelines for Disaster Victims Evacuation Model Development with Corona Virus Disease 2019 Pandemic
}

\author{
Muhammad $^{1,2}$, Hajjul Kamil ${ }^{* 3}$, Adlim $^{3}$, Irwandi $^{4}$ \\ ${ }^{1,3}$ Graduate School of Mathematics and Applied Sciences, Universitas Syiah Kuala, Banda Aceh \\ 23111, Indonesia \\ ${ }^{2}$ Nursing Department of Aceh health Polytechnic, Ministry of Health, Aceh, Indonesia \\ ${ }^{3}$ Nursing Leadership and Management Department, Faculty of Nursing, Universitas Syiah Kuala, \\ Banda Aceh, 23111, Indonesia \\ ${ }^{4}$ STEM Research Center (STEM - id), Universitas Syiah Kuala, Aceh Indonesia \\ *Corresponding author :Hajjul Kamil, haijul.kamil@unsyiah.ac.id
}

\begin{abstract}
In developing the disaster victim evacuation (DVE) model, we started with exploratory study is needed to identify the related variables. The exploratory studies are in the form of qualitative and quantitative research. In this qualitative study conducted agent-based in the nursing perspective. To conduct this research, guidelines are needed that are in accordance with the actual situation, such as the global COVID-19 pandemic. Although many articles have been published regarding in-depth interview (II) and Focus Group Discussion (FGD) guidelines, all of them have to be readjusted according to the situation. This adjustment is important to do minimize problems that arise in the data collection process, such as the emergence of new clusters during pandemic of the Covid 19. This study aims to provide a detailed standard in the implementation of the data collection process using the II \& FGD method for the DVE Model development and in accordance with pandemic conditions.This literature review study begins with article search and identification of scientific articles. Before the scientific articles are synthesized, a variable identification process is carried out through 2 stages, namely identification to sort articles according to variables and article selection for research main reference needs and references for discussion.. The results of this study are in the form of qualitative research guidelines presented in the form of standard data collection methods using II \& FGD. In this article, we recommend aligning the II \& FGD guidelines with the development of information technology in exploring Agent-based information.
\end{abstract}

Keywords: In-depth Interview, FGD, disaster \& Model

\section{Introduction}

The beginning of the Corona Virus Disease (Covid 2019) pandemic has messed up the implementation of health services and research (Henage et al., 2021). In a short time all elements must adjust their standard procedures with anti-virus protocols(Alarcon-Ruiz et al., 2021). If this is ignored, it will be identified as the cause of the new cluster of virus spread. For this reason, all service and research activities that involve individuals in the process must immediately make adjustments to the standard procedures (Alarcon-Ruiz et al., 2021).

Qualitative research guidelines, for example, must be able to guide and facilitate studies during the Covid 19 pandemic. The data collection process will be carried out on communities that are under the threat of Covid 19 (Y. Lee E. at. al, 2020). Guidelines for collecting qualitative research data as a product of this study were made to be a reference and guide for researchers in the process of collecting data in finding content.(Kamil, H; at., al, 2020) which is the target of exploration (Raingruber, 2014). In practice, the researcher will consistently improve the questions until the data collection process reaches saturation (Achmad Rizal H. Bisjoe, 2018) and in accordance with the concept of data collection (Renz, 
Carrington, \& Badger, 2018). The exploration targets were stated based on the literature study conducted previously. The content is the initial basis in preparing documents or formats related to questions asked in the in-depth interview process (II) and Focus Group Discussion (FGD) guidelines. Agee (2009), (Rachmawati, 2007) and Hashimov (2015). In the usual guidelines also contain an explanation of how to analyse (Wijaya, 2018).

II and FGD are 2 methods of collecting data from individuals that are commonly used in nursing research (Rachmawati, 2007), in addition to documents and literature review(Petkovic et al., 2020). II is a method of collecting personal data in a limited amount to capture detailed information about the characteristics and performance of individuals or institutions and obtain in-depth information related to new problems.(Creswell, 2009). Meanwhile, FGD is a data collection technique commonly used in qualitative research. The validity and reliability of data collection in qualitative research can be achieved by conducting the FGD process properly (King et. al (2010). The method introduced by Kurt Lewin in 1936 (Achmad Rizal H. Bisjoe, 2018), can record differences and diversity of opinion related to the focus of the discussion. In the FGDs, in a forum, resource persons from various components of the community, activists in related fields have been collected (Sufri, 2020).

Conducting a literature review at the beginning of the research becomes an important thing at the beginning of the study, especially in determining the research problem (Petkovic et al., 2020). In addition, this method is also very powerful in finding and finding new investigative strategies, exploiting understanding methodologies, and providing opinions for alternative solutions for future studies (Randolf, 2009), (Sufri, 2020)). This literature review is used to explore resources, and the obstacles that have been faced in the past become potentials and challenges to improve the ability of the government and society to face the threat of disasters.(Dhingra \& Roy, 2015a). This is an important point that becomes the main point of view in the process of compiling guidelines for in-depth interviews and FGDs related to resource exploration studies and constraints in developing disaster victim evacuation scenarios. Resources and constraints in disaster management efforts that have been revealed and practiced throughout the world in the past have become the basis for comparison in a qualitative study to be conducted in Aceh related to the Evacuation of Disaster Victims (DVE). This study aims to provide a detailed reference in the implementation of process II \& FGD for the development of the DVE model

\section{Method}

In the framework of a qualitative research process with the theme of resource exploration and constraints in the process of evacuating disaster victims, our researchers compiled guidelines for in-depth interviews and Focus Group Discussions. The preparation and adjustment of the guidelines was carried out using the Literature Study. These were chosen with the aim of gaining methodological insight and limiting the issues to be addressed in future research (Randolph, 2009) namely regarding the components related to the evacuation of disaster victims.

This literature review study was carried out by synthesizing scientific articles that discussed standards and data collection processes in the form of II \& FGD, especially studies related to disasters. However, due to the ongoing Covid 19 pandemic, adjustments are needed in every step that will be taken in the data collection process with II \& FGD. This adjustment process is studied through actual literature studies that pay attention to face-toface health protocols during the COVID-19 pandemic (Y. Lee E. at. al, 2020).

The procedure taken before the preparation of guidelines or implementation standards for data collection is carried out by searching and identifying scientific articles related to DVE, which refer to (Randolph, 2009) \& (Petkovic et al., 2020). Namely (1) 
Identification of variables to sort out articles as needed, (2) selection of articles for the needs of the main research references and references for variable discussion, (3) Conducting the synthesis process of selected valid articles.

\section{Results and Discussion}

\section{In-depth Interview Standards in the Covid-19 Pandemic}

A.Standard Preparation / Input

This process includes the preparation of the Inform Concent, the preparation of a list of in-depth interview questions, the preparation of the resource persons, as well as the preparation of logistics and venues (Henage et al., 2021). Standards related to Preparation of Permits and Inform Concent, namely Providing a Permit Application Letter to Become a Resource Person (Rawson, at. al 2019). In addition, providing a cover letter and research information sheet and providing permission or a letter of willingness to be a resource person (Rawson, at. al 2019).

Table 1: In-depth Interview Preparation

\begin{tabular}{ll}
\hline Preparation category & \multicolumn{3}{c}{ Preparation type } \\
\hline Framework & $\begin{array}{l}\text { Fremework plan, administrative preparation, licensing and } \\
\text { ethical clearance }\end{array}$ \\
\hline Source person & $\begin{array}{l}\text { Identification of resource persons and their institutions, } \\
\text { Selection, determination of main and backup sources and } \\
\text { establishing and maintaining cooperation }\end{array}$ \\
\hline Material Preparation & Hand Sanitizer, Recorders, and Stationary \\
\hline $\begin{array}{l}\text { Preparation time and } \\
\text { place }\end{array}$ & Scheduling, determination and arrangement of places II \\
\hline
\end{tabular}

In the Preparation of Guide II (Petkovic et al., 2020) \& (Rachmawati, 2007) Limits to note include:

a. The preparation of the guide is made based on the purpose or need for the data and information to be extracted, and carried out carefully

b. Interview material is included in the in-depth interview guide

c. The in-depth interview guide contains the objectives of the Research. purpose of the interview, the type of information to be obtained, Aspects/Indicators, list of questions, time and resource persons.

d. The questions compiled are media that can reveal and explain the things referred to in the problem formulation and other things related to research.

e. Make questions that can dig up relevant information and can answer research questions.

f. The order of questions is made from general questions to more specific questions.

$\mathrm{g}$. The preparation of questions is done by choosing simple, clear and easy to understand language

h. Provide a Recording Sheet that is approximately 4 to 5 in length including a column or space to record responses to participant comments.

i. Do a test

Standards for resource preparation that need to be considered include (a) Identification of resource persons according to sampling procedures or inclusion and exclusion criteria. (b) Identification of resource persons according to information needs related to research questions(Rawson et al., 2019). For preparation of supplies/logistics, the standard things that need to be provided are stationery and documentation tools and 
other supporting equipment. For preparation standards related to the determination and arrangement of the interview venue, the ideal criteria that must be met are Neutral, safe and comfortable for the resource persons. For the effectiveness of the interview process, it is necessary to arrange chairs and tables so that the interviewer and resource person sit facing each other (Rachmawati, 2007)\&(Creswell, 2009).

The questions raised are based on the main focus of research and review journals related to the evacuation of disaster victims. The questions that will be asked in the indepth interview process are related to several types of information, namely the availability and affordability of protocols, resources and obstacles in the evacuation of disaster victims. In the type of resource and constraint information, it includes questions related to information about resources related to Human resources, Vehicles, Routes, victim conditions and travel time.(Djalali, at. al, 2011) \& (Dhingra \& Roy, 2015b).

\section{B. Process Standard}

The interview process is carried out by choosing a location that is affordable by the resource persons (Feizolahzadeh et al., 2019). In this guide, the place for the in-depth interview is chosen where the resource person works. This is done with a background to make it easier for sources to show work documents and their convenience (Petkovic et al., 2020).

Prior to the interviews, the researchers took health protocols and ethical procedures. The health protocol includes washing hands before entering the interview room, wearing a mask and adjusting a minimum sitting position with a distance of 1.5 meters and cleaning the recording device before and after use. The ethical procedures adopted were an explanation of the objectives and benefits of the research for the informants, explaining the research procedures and interview procedures, and asking for approval from the informants to participate in the interview activities through signatures on the Inform Concern section.(Alarcon-Ruiz et al., 2021).

After that, the interviewer also asked for permission to place the position of the recording device close to the resource person and audio-record the interview process. To guide the in-depth interview, it is best to do it by the researcher himself to maintain the focal point of the interview process. Qualitative researchers always pay attention to the following things:

a. Set the ideal sitting position where the interviewer and the interviewee sit opposite each other, which allows the interviewer to easily catch the non-verbal expressions of the participants.

b. Place a recording device between the interviewer and the interviewee so that both voices can be recorded properly. When the recording process starts, press the "on" button correctly.

c. The interviewer explains the purpose and objectives of the interview and the procedure for conducting the interview, including permission to record the conversation. Which is followed by giving informed consent to the prospective resource persons

d. Interviewer Observing and responding to reactions, controlling tone of voice, body gestures and maintaining a conducive atmosphere

e. Respect participants, always be polite, listen more than talk and avoid giving arguments.

f. The interviewer is able to control the time according to the questions and stay focused on the objectives and interview material

g. Documenting the interview process and results through notes, recordings and photos.(Fathurrohman, 2018), (Robinson, 2014) \& (Rachmawati, 2007) 


\section{Closing and Evaluations Standards}

The last process that is very important to be considered by the researcher before ending the interview is the result. The main benchmark that needs to be considered is the identification of factors related to the research objectives and from the interviews obtained, recommendations can be made for plans to develop data collection instruments.(Rachmawati, 2007). To evaluate the effectiveness of the health protocol, an assessment of the health of the informants was carried out 15 days after the interview(Taha et al., 2020).

\section{FGD Standards on Covid 19 Pandemic}

In carrying out the FGD which includes 3 main stages, namely preparation, process and evaluation of the results by taking into account the operational standards commonly used.

\section{A. Standard Preparation /Input}

In the category of FGD preparation, it includes team preparation, preparation of Terms of Reference and permits, preparation of materials, equipment and places as well as preparation of participants or resource persons. Next prepare the appropriate recording device(Henage et al., 2021)like mike. Mike must be sensitive enough to record conversations especially if the room does not have a good acoustic structure. And Check the condition of the battery recorder, memory, and functioning properly.(Achmad Rizal H. Bisjoe, 2018).

The following is a list of activity standards that must be met:

Table 2: Preparation of FGD

\begin{tabular}{ll}
\hline Preparation category & \multicolumn{1}{c}{ Preparation point } \\
\hline Team Preparation & $\begin{array}{l}\text { Identification of members, Selection of Members, Division of roles } \\
\text { and Assignment of roles }\end{array}$ \\
\hline $\begin{array}{l}\text { Work plan and } \\
\text { Licensing }\end{array}$ & $\begin{array}{l}\text { Provision of Terms of Reference, administrative process, Licensing } \\
\text { and Inform Concent }\end{array}$ \\
\hline Participant & $\begin{array}{l}\text { Identification of participants and institutions and participant } \\
\text { backgrounds, Selection, Determination of respondents and reserve } \\
\text { participants and fostering cooperative relationships with participants } \\
\text { \& institutions from which participants come }\end{array}$ \\
\hline Material Preparation & Stationery, Consumption, Recording Equipment, Record Book \\
\hline $\begin{array}{l}\text { Preparation time and } \\
\text { place }\end{array}$ & $\begin{array}{l}\text { Arrangement of Schedules, Selection of places, Procurement of } \\
\text { places \& facilities and Arrangement of places }\end{array}$ \\
\hline
\end{tabular}

The initial process that needs to become a standard that must be carried out is Team Formation and division of roles. From (Moretti et al., 2011) and (Achmad Rizal H. Bisjoe, 2018) it can be underlined that the team needed according to the role of each individual is a moderator, assistant moderator, note taker and participant liaison.

Table 3 Roles of FGD Implementation Team Members

\begin{tabular}{|c|c|}
\hline TEAM member & Role\& Activity \\
\hline Moderator/Facilit & ct as a regulator of the discussion, both substantive and proce \\
\hline $\begin{array}{l}\text { Assistant } \\
\text { Moderator/co } \\
\text { facilitator }\end{array}$ & $\begin{array}{l}\text { Las a role in observing the FGD process and assisting the } \\
\text { Moderator/Facilitator in controlling time, focus of discussion, } \\
\text { discussion material and active role of participants }\end{array}$ \\
\hline
\end{tabular}




\begin{tabular}{ll}
\hline Notes & $\begin{array}{c}\text { he role of recording the process, and the material problems } \\
\text { discussed. Equipped with laptop and recording device }\end{array}$ \\
\hline Participant liaison & $\begin{array}{c}\text { he role of contacting and ensuring the presence of participants (local } \\
\text { partners) }\end{array}$ \\
\hline Logistics Provider & $\begin{array}{l}\text { lay a role in: providing transportation, resting needs, consumption } \\
\text { and accommodation }\end{array}$ \\
\hline $\begin{array}{l}\text { Documentation } \\
\text { officer }\end{array}$ & rocess documentation and document collection \\
\hline General officer & 'leanliness, safety, etc \\
\hline
\end{tabular}

Furthermore, after the team is formed together can determine the place and arrangement. In determining the location or place for the FGD to be held, it is necessary to pay attention to the criteria for the ideal place, namely neutral, safe and comfortable. In arranging the place, the choice that needs to be made is whether to choose to use a chair or not, because it is related to the facilities to be used. In addition, the arrangement of the sitting position also needs to be considered (Oktari, at. al, 2018). Participants can choose a half or three quarter circle formation. This formation is adjusted to the outdoors and the number of participants. In addition, the moderator/facilitator is at the focal point of the FGD participants. For FGD logistics preparation, materials that must be available include: stationery, documentation tools and Audio Visual Aid. In addition, pay attention to consumption, accommodation, sanitation tools and materials and other supporting equipment (Achmad Rizal \& H. Bisjoe, 2018).

Before preparing the venue and the logistics of the discussion, it is also important to guide the selection of participants, namely: Minimum 4 participants and maximum 12 people. In determining the participants, the considerations are the background of the participants, the diversity and depth of information (Henage et al., 2021). In considering diversity, one must pay attention to the characteristics of homogeneity or heterogeneity of the participants, because this is related to the objectives of the FGD. The above considerations are important to avoid FGD failure. There are several causes of FGD failure identified by Irwanto (2006) in (Achmad Rizal \& H. Bisjoe, 2018). namely: Character of participants, group dynamics and time constraints.

In preparing the questions in the FGD, the limitations that became the standard and were considered include: the preparation of questions in the FGD based on the context that underlies the research objectives or the data and information needs to be explored. In addition, the preparation of FGD materials was carried out carefully. The provision of guidelines when discussing is important in guiding the discussion process so that it can run in a structured manner and not go out of the direction of the discussion that has been determined. The guidelines contain the objectives of the research, the objectives of the FGD, the type of information to be obtained, a list of questions and a recording sheet (Moretti et al., 2011).

In providing a list of questions and recording sheets to obtain discussion results that can answer and explain the matters referred to in the research problem formulation or other matters related to the problem being discussed. The list of discussion questions is made from general questions to more specific questions. discussion questions need to choose simple, clear and easy to understand language and go through a trial process(Moretti et al., 2011)

B. FGD Implementation Standards

Participants enter the discussion room, by implementing infection protection behaviors, namely washing hands, maintaining hygiene and wearing masks (C Den Daas, 
at. al, 2021). The FGD implementation procedure was carried out through the opening, discussion and closing steps. The opening relates to an explanation of the content and discussion process as well as the dissemination of informed consent and approval to become a discussion participant (Kamil, H, at. al, 2020). The opening phase consists of the following sequence of activities (Kamil, H, at. al, 2020), (Achmad Rizal H. Bisjoe, 2018)\&(C Den Daas, at. al, 2021):

Table 4 Implementation Standards for FGD activities

\begin{tabular}{|c|c|}
\hline Category & \\
\hline $\begin{array}{l}\text { Environmental } \\
\text { control }\end{array}$ & $\begin{array}{l}\text { 1. Room arrangement: minimum size } 6 \times 8 \mathrm{~m} 2 \text { with } \mathrm{AC} \text { facilities } \\
\text { 2. Seating position arrangement: Circular formation with a focus point on the } \\
\text { facilitator with an average distance of } 2 \text { meters between participants } \\
\text { 3. Putting the recording device: In the middle of the circle and within the } \\
\text { reach of the participants }\end{array}$ \\
\hline $\begin{array}{ll}\text { Prevention of } \\
\text { Covid } 19 \\
\text { Transmission }\end{array}$ & $\begin{array}{l}\text { Accept the presence of participants at the entrance, encourage participants } \\
\text { to wash their hands before entering the discussion room, encourage } \\
\text { participants to always use masks while in the discussion room and } \\
\text { encourage participants to sit in the space provided }\end{array}$ \\
\hline $\begin{array}{l}\text { Resear } \\
\text { Ethics }\end{array}$ & $\begin{array}{l}\text { dures for conducting FGD } \\
\text { s \& give informed consent }\end{array}$ \\
\hline Documentation & button on the recorder when recording starts. \\
\hline $\begin{array}{l}\text { Implementation } \\
\text { of Discussion } \\
\& \text { evaluation of } \\
\text { results }\end{array}$ & $\begin{array}{l}\text { 1. Time } 90 \text { minutes } \\
\text { 2. Creating a safe and comfortable discussion atmosphere } \\
\text { 3. Documentation of discussion materials \& participants' psychological } \\
\text { atmosphere } \\
\text { 4. Evaluation of the achievement of discussion content }\end{array}$ \\
\hline
\end{tabular}

In the FGD process, the moderator's standard of behavior includes the standard of duty and the standard of attitude. The moderator's duties are (1) to explain the aims and objectives of the FGD, (2) to explain the topics and main issues of discussion, (3) to explain the procedures for conducting the discussion, to create a conducive atmosphere, (4) to manage group dynamics, (5) to observe and be responsive to participants' reactions, (6) pay attention to tone of voice, (7) avoid giving personal opinions, (8) avoid agreeing/disagreeing comments, (9) paying attention to body gestures and (10) being able to control time(Achmad Rizal H. Bisjoe, 2018).

Meanwhile, the standard attitude that must be possessed by the moderator is (a) having flexibility, sensitivity, humor, building shared ideas, encouraging participation from all participants. In addition, the moderator should avoid dictating the course of the discussion, losing control of the conversation, judging the opinions of the participants, acting like an expert and directing the participants to the Q\&A session.(Achmad Rizal \& H. Bisjoe, 2018). according to (Henage et al., 2021) that there are 4 types of opinions raised by discussion participants, namely: sharing, comparing conceptuazing/organizing and validating

In addition to the things mentioned above, the standard time that is generally used is 90 minutes. Includes time to log, start time, break and end time. As well as documentation standards, namely written documentation and audio recordings, and preferably accompanied by photo documents (Achmad Rizal H. Bisjoe, 2018). 


\section{Results / Output Standards}

Identified factors related to resources and constraints for the evacuation of disaster victims and made recommendations for the plan to develop data collection instruments (Moretti et al., 2011). For post-discussion health protocols, the organizers recommend that participants wash their hands and change clothes when they get home, in addition to conducting a covid 19 check. The organizers also assess the health conditions of participants 15 days after the discussion.(Taha et al., 2020).

\section{Conclusion and Recommendation}

This guideline for collecting data using the II \& FGD method has been adapted to the COVID-19 pandemic situation and continues to be adapted to the needs of research questions to find components related to the development of the DVE model.

In this article, we also recommend aligning the II \& FGD guidelines with the development of information technology in exploring Agent-based information, or for developing operational procedure models.

\section{References}

Achmad Rizal H. Bisjoe. (2018). Menjaring Data dan informasi penelitian melalui Focus Group Discussion(FGD ): Bbelajar dari Praktek Lapangan. Info Teknis EBONI, Vol. 15 No, 17-28.

Agee, J. (2009). Developing qualitative research questions: A reflective process. International Journal of Qualitative Studies in Education, 22(4), 431-447. https://doi.org/10.1080/09518390902736512

Alarcon-Ruiz, C. A., Villarreal-Zegarra, D., Melendez-Torres, G. J., Torres-Puente, R., Ambrosio-Melgarejo, J., Romero-Cabrera, A. B., ... Huarcaya-Victoria, J. (2021). Development of a framework for the implementation of synchronous e-mental health: A protocol for a realist synthesis of systematic reviews. F1000Research, 9(October). https://doi.org/10.12688/f1000research.27150.2

Creswell, J. W. (2009). Research Design Qualitative, Quantitative, and Mixed Methods Approaches.

Den Daas, C., Hubbard, G., Johnston, M., \& DIxon, Di. (2021). Protocol of the COVID-19 Health and Adherence Research in Scotland (CHARIS) study: Understanding changes in adherence to transmission-reducing behaviours, mental and general health, in repeated cross-sectional representative survey of the Scottish populat. BMJ Open, 11(2). https://doi.org/10.1136/bmjopen-2020-044135

Dhingra, V., \& Roy, D. (2015a). Modeling emergency evacuation with time and resource constraints: A case study from Gujarat. Socio-Economic Planning Sciences, 51, 23-33. https://doi.org/10.1016/j.seps.2015.06.001

Dhingra, V., \& Roy, D. (2015b). Modeling emergency evacuation with time and resource constraints: A case study from Gujarat. Socio-Economic Planning Sciences, 51, 23-33. https://doi.org/10.1016/j.seps.2015.06.001

Djalali, A., Khankeh, H., Öhlén, G., Castrén, M., \& Kurland, L. (2011). Facilitators and obstacles in pre-hospital medical response to earthquakes: A qualitative study. Scandinavian Journal of Trauma, Resuscitation and Emergency Medicine, 19, 1-9. https://doi.org/10.1186/1757-7241-19-30

Fathurrohman, M. P. (2018). Analisis Pengadaan Koleksi buku teks Pelajaran dalam menunjang Kegiatan Belajar Siswa. Universitas Pendidikan Indonesia|repository.Upi.Edu|perpustakaan.Upi.Edu. 
Feizolahzadeh, S., Vaezi, A., Mirzaei, M., Khankeh, H., Taheriniya, A., Vafaeenasab, M., \& Khorasani-Zavareh, D. (2019). Barriers and facilitators to provide continuity of care to dischargeable patients in disasters: A qualitative study. Injury, 50(4), 869-876. https://doi.org/10.1016/j.injury.2019.03.024

Hashimov, E. (2015). Qualitative Data Analysis: A Methods Sourcebook and The Coding Manual for Qualitative Researchers. Technical Communication Quarterly, 24(1), 109112. https://doi.org/10.1080/10572252.2015.975966

Henage, C. B., Ferreri, S. P., Schlusser, C., Hughes, T. D., Armistead, L. T., Kelley, C. J., ... Roberts, E. (2021). Transitioning Focus Group Research to a Videoconferencing Environment: A Descriptive Analysis of Interactivity. Pharmacy, 9(3), 117. https://doi.org/10.3390/pharmacy9030117

Kamil, H; R, Rachmah; Wardani, E; Bjorvell, C. (2020). How to Optimize Integrated Patient Progress Notes : A Multidisciplinary Focus Group Study in Indonesia.

Moretti, F., Vliet, L. Van, Bensing, J., Deledda, G., Mazzi, M., Rimondini, M., ... Fletcher, I. (2011). Patient Education and Counseling A standardized approach to qualitative content analysis of focus group discussions from different countries. Patient Education and Counseling, 82(3), 420-428. https://doi.org/10.1016/j.pec.2011.01.005

Oktari, R. S., Shiwaku, K., Munadi, K., Syamsidiq, \& Shaw, R. (2018). Enhancing community resilience towards disaster: The contributing factors of school-community collaborative network in the tsunami affected area in Aceh. International Journal of Disaster Risk Reduction, 29, 3-12. https://doi.org/10.1016/j.ijdrr.2017.07.009

Petkovic, J., Riddle, A., Akl, E. A., Khabsa, J., Lytvyn, L., Atwere, P., ... Tugwell, P. (2020). Protocol for the development of guidance for stakeholder engagement in health and healthcare guideline development and implementation. Systematic Reviews, 9(1), 1-11. https://doi.org/10.1186/s13643-020-1272-5

Rachmawati, I. N. (2007). Pengumpulan data dalam Penelitian Kualitatif: Wawancara. Jurnal Keperawatan Indonesia, 11 no 1, 35-40.

Raingruber, B. (2014). Health Promotion Theories. Contemporary Health Promotion in Nursing Practice, 53-94. Retrieved from http://books.google.co.id/books?id=GeGq5tJlVHYC\&printsec=frontcover\&dq=bonnie + raingruber+health + promotion + theory + jones $+\&+$ bartlett + learning $\& h l=e n \& s a=X \& e i=v Y$ RvU6TgAcH-rAfn0IDgBg\&redir_esc $=\mathrm{y} \# \mathrm{v}=$ onepage \&q\&f $=$ false

Randolph, J. J. (2009). A guide to writing the dissertation literature review. Practical Assessment, Research and Evaluation, 14(13).

Rawson, R. A., Rieckmann, T., Cousins, S., McCann, M., \& Pearce, R. (2019). Patient perceptions of treatment with medication treatment for opioid use disorder (MOUD) in the Vermont hub-and-spoke system. Preventive Medicine, 128(July), 105785. https://doi.org/10.1016/j.ypmed.2019.105785

Renz, S. M., Carrington, J. M., \& Badger, T. A. (2018). Two Strategies for Qualitative Content Analysis: An Intramethod Approach to Triangulation. https://doi.org/10.1177/1049732317753586

Robinson, O. C. (2014). Sampling in Interview-Based Qualitative Research: A Theoretical and Practical Guide. Qualitative Research in Psychology, 11(1), 25-41. https://doi.org/10.1080/14780887.2013.801543

Sufri, S. (2020). Community Engagement in the Early Warning System to Improve Disaster Preparedness in Aceh Province, Indonesia. Griffith Research Online. https://doi.org/https://doi.org/10.25904/1912/1931 Copyright 
Taha, M. A., Hall, C. A., Rathbone, R. F., Corsten, L. A., Bowie, C. R., Waguespack, P. J., ... Barham, H. P. (2020). Rhinologic Procedures in the Era of COVID-19: Health-care Provider Protection Protocol. American Journal of Rhinology and Allergy, 34(4), 451455. https://doi.org/10.1177/1945892420927178

Wijaya, H. (2018). Ringkasan dan Ulasan Buku Analisis Data Penelitian Kualitatif (Prof. Burhan Bungin), (March).

Y. Lee E. Lee P. Chew E. Muthulingam G. Koh H. Tan S. Ding. (2020). Video Consultations for Older Adults With Multimorbidity During the COVID-19 Pandemic: Protocol for an Exploratory Qualitative. JMIR Res Protoc. 